\title{
ANALISIS STRATEGI PROMOSI TABUNGAN FAEDAH PT. BRI SYARIAH KC. BANJARMASIN
}

\author{
Nur Habibah \\ Magister Ekonomi Syariah, IAIN Palangkaraya \\ nurhabibah151@gmail.com \\ Ahmad Dakhoir \\ Magister Ekonomi Syariah, IAIN Palangkaraya \\ ahmad.dakhoir@iain-palangkarya.ac.id
}

\begin{abstract}
This study aims to describe and analyze using the SWOT method of promotion strategies carried out at PT. BRI Syariah KC Banjarmasin. The type of research used is field research with a qualitative approach. Then, the research data source is primary data that comes directly from the field. To obtain research data, data collection techniques by observation, interviews with MO (Operational Manager) FRO (Funding Relations Officer) and AO (Account Officer), and documentation. Then to analyze the data used analysis techniques of editing, categorization, and description. The results showed that the promotion strategy of Faedah savings carried out by BRI Syariah KC Bajarmasin which was carried out in the form of: promotion when attacking the market, elementary school, junior high school, high school, company, college, collaborating with several companies and to prospective customers who want to make financing. Based on the SWOT analysis, BRI Syariah KC Banjarmasin still has many challenges and weaknesses that must be addressed so that the promotion is successful and helps to increase third party funds at BRI Syariah KC Banjarmasin.
\end{abstract}

\section{Keywords: SWOT Analysis, Promotion Strategy, Savings Benefits}

\begin{abstract}
Abstrak
Penelitian ini bertujuan untuk mendeskripsikan dan menganalisis menggunakan metode SWOT strategi promosi yang dilakukan di PT. BRI Syariah KC Banjarmasin. Jenis penelitian yang digunakan adalah penelitian lapangan dengan pendekatan kualitatif. Kemudian, sumber data penelitian merupakan data primer yang berasal langsung dari lapangan. Untuk mendapatkan data penelitian, teknik pengumpulan data dengan observasi, wawancara bersama MO (Manajer Operasional) FRO (Funding Relation Officer) dan AO (Account Officer), dan dokumentasi. Kemudian untuk menganalisis data digunakan teknik analisis editing, kategorisasi, dan deskripsi. Hasil penelitian menunjukkan strategi promosi tabungan Faedah yang dilakukan BRI Syariah KC Bajarmasin yang dilakukan berupa: promosi ketika serbu pasar, kesekolahan SD, SMP, SMA, perusahaan, keperkuliahan, bekerjasama dengan beberapa perusahaan dan ke calon nasabah yang ingin melakukan pembiayaan. Berdasarkan analisis SWOT, BRI Syariah KC Banjarmasin masih memiliki banyak tantangan dan kelemahan yang harus dibenahi agar promosi yang dilakukan berhasil dan membantu menambah dana pihak ketiga pada BRI Syariah KC Banjarmasin.
\end{abstract}

Kata kunci : Analisis SWOT, Strategi Promosi, Tabungan Faedah 


\section{Pendahuluan}

Lembaga keuangan perbankan memiliki fungsi dan peran penting dalam meningkatkan pertumbuhan ekonomi dan kesejahteraan masyarakat. Sebagai lembaga intermediasi, bank memiliki fungsi menghimpun dana berupa deposito, giro, tabungan yang nantinya akan disalurkan kembali pada nasabah yang memerlukan dana melalui produk-produk kredit yang ada pada suatu bank tersebut (Suryaputra, Bandi, \& Setiawan, 2017).

Dana operasional bank berasal dari dana pihak ketiga, yang mana pada bank disebut sebagai tabungan. Baik bank konvensional ataupun syariah membutuhkan nasabah untuk menabung pada produk tabungan yang ada pada bank tersebut. Pada penelitian ini, menggunakan bank syariah sebagai objek penelitian. Pada dasarnya secara fungsi bank syariah memiliki kesamaan dengan bank konvensional. Hanya saja bank syariah beroperasi sesuai dengan prinsip-prinsip alQuran dan al-Hadits. Dalam proses transaksinya menggunakan akad-akad dalam muamalah dan bebas dari transaksi yang mengandung riba, maysir, gharar, dan najasy.

Kasmir (2012) dalam bukunya mengatakan bahwa bank syariah sebagai salah satu lembaga keuangan yang telah memberikan warna baru dalam kehidupan sosial ekonomi masyarakat Indonesia. Kehadirannya seakan menjadi solusi terhadap berbagai keterpurukan ekonomi yang dihadapi oleh negeri ini. Asas keadilan, keterbukaan dan kemitraan yang menjadi prinsip bank syariah adalah nilai tersendiri yang mencoba ditawarkan oleh bank syariah.

Salah satu bank syariah yang sudah beroperasi lama di Indonesia adalah PT. BRI Syariah. BRI Syariah yang sebelumnya merupakan anak usaha syariah dari PT. BRI memisahkan diri sejak tahun 2008 menjadi PT. BRI Syariah. Dan hingga saat ini sudah tersebar luas dan memiliki cabang diseluruh provinsi di Indonesia. Salah satu yang menjadi produk unggulan adalah tabungan Faedah.

Pada tahun 2019 berdasarkan berita yang dilansir dari Republika, tabungan faedah BRI Syariah jadi favorit millenial. Dengan begitu, BRI Syariah mendapat penghargaan diacara Top Brand Award 2019 kategori Tabungan Syariah. Promosi yang dilakukan tanpa biaya, hanya menggunakan media sosial BRI Syariah. Selain itu, generasi millenial tertarik dengan mobile banking BRI Syariah yaitu BRIS Online karena memiliki kemudahan bertransaksi, kemudian dilengkapi dengan fitur lengkap dengan konten islami yang kekinian.

Pandemi Covid-19 ini menimbulkan perubahan perilaku masyarakat, tidak terkecuali hubungannya dengan transaksi keuangan. Perbankan syariah pun terkena imbasnya, pembukaan tabungan yang biasanya dilakukan secara langsung oleh customer service harus terbatas selama pandemi. Kemampuan menyesuaikan diri dengan keadaan tersebut mengharuskan BRI Syariah untuk memiliki strategi yang tepat untuk bertahan dan tetap dapat menambah nasabah tabungan faedah.

Dalam melakukan strategi tentunya ada beberapa promosi yang dilakukan oleh pihak perusahaan untuk menjelaskan jika memang produk itu baru dan menginformasikan bahwa produk yang baru tidak kalah bagusnya dengan produk yang lama. "Promotion is a move to an important job or rank in a company organization, an activity intented to belp sell a product, the activty of persuachving people to support idea, the activity of helping something develop and succed'. (Ma'arif, 2008). Strategi promosi yang akan dijalankan, suatu perusahaan harus melihat situasi dan kondisi pasar serta menilai kedudukan atau posisi perusahaan dipasar. Khususnya di kota Banjarmasin di BRI Syariah KC Banjarmasin banyak menawarkan berbagai jenis produk tabungan yang berkarakter syariah, salah satunya adalah produk tabungan Faedah.

Berdasarkan observasi awal ada berbagai strategi promosi yang dijalankan oleh pihak BRI Syariah KC Banjarmasin dalam rangka mempromosikan produk Faedah, adapun beberapa 
upaya yang dilakukan untuk menarik minat nasabah dalam menabung yaitu (1) sosialisasi; (2) periklanan; (3) promosi dengan cara serbu pasar yang dilakukan oleh Funding Relation Officer (FRO) dan Account Officer (AO) secara terjadwal 1 (satu) kali dalam seminggu; (4) berkunjung ke sekolah seperti SD, SMP, SMA; (5) kampus; (6) bekerjasama dengan beberapa perusahaan. (Handayani, 2018).

Salah satu tujuan promosi bank adalah menginformasikan segala jenis produk yang ditawarkan dan berusaha menarik calon nasabah yang baru. Kemudian promosi juga berfungsi mengingatkan nasabah akan produk, promosi juga mempengaruhi nasabah untuk membeli dan akhirnya promosi juga akan meningkatkan citra bank dimata nasabahnya. Oleh sebab itu promosi sangat penting dilakukan oleh suatu bank dalam meningkatkan nasabahnya (Waroh, 2020).

Strategi promosi yang dilakukan di atas merupakan strategi promosi pada keadaan normal, maksudnya adalah saat belum terjadi pandemi. Maka dari itu, penelitian ini bertujuan untuk mendeskripsikan strategi promosi tabungan faedah PT. BRI Syariah dan menganalisis menggunakan metode SWOT sehingg dapat dilihat apakah pada masa Covid-19 ini, masih efektif digunakan atau tidak.

\section{Metode}

Penelitian ini merupakan penelitian lapangan, yang mana pengumpulan data dilakukan ditempat fenomena. Kemudian, menggunakan pendekatan kualitatif dimana hasil penelitian dideskripsikan melalui kalimat verbal yang mudah dipahami. Penelitian lapangan ini berlokasi di kantor BRI Syariah Kantor Cabang Banjarmasin terletak pada Jalan Ahmad Yani No. 147 C, Kebun Bunga, Kecamatan. Banjarmasin Timur, Kota Banjarmasin, Kalimantan Selatan. Data penelitian ini berasal dari data primer, dimana teknik pengumpulan data dilakukan dengan cara observasi ke lokasi, wawancara dengan MO (Manajer Operasional) FRO (Funding Relation Officer) dan AO (Account Officer), dan dokementasi berupa data-data BRI Syariah dari arsip dan studi kepustakaan. Analisis data Analisis data yang digunakan dalam penelitian ini adalah teknik analisis deskriptif kualitatif, yang dilakukan dengan tiga tahapan, yaitu editing, kategorisasi, dan deskripsi.

\section{Hasil dan Pembahasan}

\subsection{Strategi Promosi Tabungan Faedah PT. BRI Syariah pada Masa Covid}

BRI Syariah KC Banjarmasin adalah lembaga keuangan yang kegiatannya menghimpun dana masyarakat dan menyalurkannya kembali kepada masyarakat, yang telah mendapat kepercayaan penuh dari nasabah yang datang dari beragam latar belakang. BRI Syariah tentunya mempunyai strategi yang kuat untuk mempromosikan, menyampaikan sesuatu atau berusaha menyakinkan publik mengenai semuaproduk atau jasa yang dimiliki, salah satunya adalah tabungan Faedah.

Berdasarkan wawancara dengan Handayani (2018), Hasbi (2019), dan Sofyan, (2019) penulis meringkas beberapa langkah promosi yang dilakukan oleh BRI Syariah KC Banjarmasin untuk tabungan faedah:

a. Strategi promosi yang dilakukan oleh BRI Syariah ada 5 (lima) diantaranya: Sosialisasi; serbu pasar; kesekolah seperti SD, SMP, SMA, kampus; dan bekerjasama dengan beberapa perusahaan. 
Pertama, sosialisasi yang diawali dengan membuat stand pada suatu acara, seminar, bazar, yang berhubungan dengan keuangan syariah dengan tujuan mengedukasi calon nasabah. Kedua, strategi serbu pasar, guna mempromosikan semua produk BRI Syariah. Sebenarnya lebih mengedukasikan calon nasabah agar mengetahui produk-produk yang ada di BRI Syariah tentang produk lama maupun produk terbaru, dan agar calon nasabah tertarik untuk membuka tabungan Faedah atau melakukan pembiayaan di BRI Syariah, dilakukan dengan cara dilakukan oleh BRI syariah pada dasarnya terjadwal satu kali dalam seminggu, namun dilihat lagi dengan situasi instansi/tempat untuk dilakukannya sosialisasi bisa atau tidaknya, kapan kira-kira instansi mengizinkan pihak BRI Syariah mensosialisasikan produk-produk, karena mereka juga perlu menyiapkan orang-orang yang bisa menghadiri acara promosi tersebut dan kesiapan mereka mendengarkan sosialisasi tersebut, yang mensosialisasikan pun bukan hanya staff Funding Relation Officer (FRO), Account Officer (AO) melainkan staf marketing pun ikut serta.

Ketiga, melakukan promosi ke sekolah seperti SD, SMP, SMA. Adapun sasarannya adalah mempromosikan kepada para guru, dan karyawan agar tertarik membuka tabungan Faedah. Keempat, Kampus adapun sasaran untuk mempromosikan tabungan Faedah adalah mahasiswa/i, para dosen, dan karyawan sehingga calon nasabah mengetahui produk-produk BRI Syariah. Kelima, bekerjasama dengan beberapa perusahaan, ketika disuatu perusahaan ingin melakukan pembiayaan, maka kita akan bekerjasama dengan perusahaan tersebut untuk bisa membiayai karyawannya. Gaji karyawan tersebut melalui BRI Syariah maka seluruh pengawainya diwajibkan membuka tabungan Faedah.

b. Macam-macam sarana untuk mempromosikan suatu produk tabungan Faedah terbagi 4: periklanan, penjualan pribadi, promosi penjualan, publisitas.

Pertama, periklanan pada BRI syariah melakukan perikalanan karena periklanan merupakan faktor terpenting dalam menunjangkegiatan promosi guna memberikan informasi mengenai produk tabungan Faedah, agar bisa membujuk calon nasabah sehingga bisa menggunakan produk tabungan Faedah, adapun periklanan yang dilakukan oleh pihak BRI syariah sebagai berikut:

1) Pemasangan billboard di jalanan,

2) Percetakan brosur digunakan untuk mempromosikan kepada nasabah atau calan nasabah,

3) Pemasangan iklan melalui koran,

4) Pemasangan iklan melalui televisi,

5) Program mobil ATM keliling, ketika mobil berangkat dari kantor menuju tempat promosi tabungan Faedah pun seperti iklan berjalan dimana semua orang bisa melihat dan mengetahui apa saja produk BRI syariah terkhusus tabungan Faedah, mobil ATM keliling juga hadir dikampus UIN Antasari Banjarmasin seminggu sekali setiap hari jum'at,

6) Pemasangan iklan pada media sosial baik itu berupa, Facebook (BRI Syariah, Twiter (@BRISyariah), Instagram (@BRISyariah), You tube (BRISyariah), dan,

7) Pemasangan melalui radio.

Periklanan digunakan untuk mendapatkan informasi tentang produk dan jasa yang digunakan ketika peluncuran produk, iklan juga bisa menjadi pengingat digunakan untuk mengingatkan kembali keberadaan BRI Syariah sekaligus produk-produk dan jasa kepada nasabah sehingga diharapkan mendorong untuk pemakaian lebih tinggi. Nasabah yang telah menggunakan produk tabungan faedah diharapkan lebih mengetahui tentang tabungan yang nasabah pakai sehingga bisa menginformasikan kembali kepada masyarakat luas, iklan juga 
sebagai pembujuk agar ketika seorang nasabah mengetahui informasi tentang tabungan Faedah mereka tertarik dan membuka tabungan Faedah.

Kedua, promosi penjualan merupakan kegiatan yang dilakukan untuk menarik minat nasabah agar tertarik membeli produk dan membuka tabungan Faedah, adapun promosi yang dilakukan Funding Relation Officer dan Account Officer. Pemberian insentif kepada setiap nasabah yang memiliki simpanan saldo diatas Rp. 500.000-, yaitu dengan 7 kemudahan berupa:

a) Pemberian hadiah bagi nasabah yang memiliki simpanan dengan saldo tertentu, adapun hadiah tersebut sebagai berikut:

(1) Bantal leher ketika seorang nasabah menabung sejumlah Rp. 2.000.000-,

(2) Mendapatkan Payung ketika seorang nasabah menabung dengan sejumlah uang Rp. 5000.00

(3) Mendapatkan tas serba guna ketika seorang nasabah membuka tabungan Haji,

(4) Jam digital, dan pulpen hanya untuk dibagikan kepada para nasabah

b) Pemberian insentif kepada nasabah, dari pertama seorang nasabah membuka tabungan Faedah.

Ketiga, penjualan pribadi, tidak hanya mempromosikan melewati periklanan BRI Syariah juga menerapkan strategi penjualan pribadi. Secara umumnya strategi penjualan pribadi dilakukan dimulai dengan pengawai Customer service, ketika seorang calon nasabah datang ke BRI Syariah mereka membutuhkan informasi atau penjelasan mengenasi jasa atau produk tabungan yang dimiliki BRI Syariah. Maka hendaknya pengawai Customer service memberikan informasi atau memberikan penjelasan mengenai jasa atau produk tabungan kepada calon nasabah mengenai keunggulan dan manfaat apa saja yang akan didapatkan ketika mereka membuka tabungan Faedah. Setelah calon nasabah mendapatkan penjelasan dari seorang Customer service diharapan masyarakat yang tadinya datang ke BRI Syariah dan telah mendapatkan informasi mengenai tabungan Faedah akan mempercayai BRI Syariah menjadi bank pilihannya dibandingkan dengan bank lainnya, dan Dilakukan FRO, $A O$ ketika mensosilisaikan suatu produk, serbu pasar, mempromosikan keperkuliahan, sekolahan, instansi dan perusahaan.

Keempat, publisitas merupakan kegiatan promosi untuk mempublikasikan suatu perusahaan dengan menjadi sponsorship pada kegiatan-kegiatan tertentu, maupun kegiatan yang bersifat sosial.

(1) Acara penting,

(2) Hubungan dengan para investor untuk melakukan pembinaan, pengaturan, dan pengawasan dengan tujuan mewujudkan kegiatan dengan teratur, wajar, efisien dan mekindungi kepentingan baik itu investor maupun masyarakat yang telah menjadi nasabah BRI syariah KC Banjarmasin,

(3) Pameran, misalnya yang dimana BRI Syariah ikut serta membuka Stand pada acara besar di asrama $\mathrm{Hj}$ setahun sekali, acara yang diadakan OJK, acara yang diadakan oleh BI dan acara yang terkaitan mengenai keuangan.

(4) Mensponsori acara, misalnya seminar yang diadakan oleh perusahaan, perkuliahan, adapun yang diberikan berupa: spanduk, umbul-umbul, souvenir, ketika terpasangnya spanduk, umbul-umbul, souvenir secara tidak langsung mereka mempromosikan BRI Syariah KC Banjarmasin, karena dapat dilihat orang yang datang ke acara tersebut. 


\section{Analisis Data}

Menurut Tjiptono, promosi adalah bentuk komunikasi pemasaran artinya aktivitas pemasaran yang berusaha menyebarkan informasi, mempengaruhi/membujuk dan atau mengingatkan pasar sasaran atas perusahaan dan produknya agar bersedia menerima, membeli dan loyal pada produk yang ditawarkan perusahaan yang bersangkutan (Tjiptono, 1997). Promosi merupakan salah satu factor penentu keberhasilan suatu program pemasaran. Promosi adalah sebuah kegiatan yang ditujukan untuk memperkenalkan, membujuk, dan mengingatkan pelanggan pada produk atau perantara .

Strategi promosi adalah kegiatan perusahaan untuk mendorong penjualan dengan mengarahkan komunikasi-komunikasi yang meyakinkan kepada pembeli (Moekijat, 2000). Tujuan utama promosi adalah menginformasikan, membujuk, serta mengingatkan pelanggan tentang produk atau perusahaan. Ditinjau dari sudut pandang ilmu ekonomi, tujuan promosi adalah menggeser kurva permintaan produk perusahaan kekanan dan membuat permintaan menjadi inelastis (dalam kasus harga naik) dan elastis (dalam kasus harga turun) (Nana, 2013).

Promosi merupakan salah satu kegiatan pemasaran yang penting bagi BRI Syariah KC Banjarmasin dalam upaya mempertahankan kelangsungan hidup perusahaan serta meningkatkan kualitas penjualan untuk meningkatkan Kegiatan pemasaran dalam hal memasarkan barang atau jasa. Strategi promosi tabungan Faedah yang dilakukan BRI Syariah KC Bajarmasin yang dilakukan berupa: promosi ketika serbu pasar, kesekolahan SD, SMP, SMA, perusahaan, keperkuliahan, bekerjasama dengan beberapa perusahaan dan ke calon nasabah yang ingin melakukan pembiayaan.

Secara keseluruhan strategi promosi yang dilakukan oleh pihak Bank yang terpenting adalah kepandaian seorang marketing menggali kebutuhan calon nasabah, mulai dari mengetahui apa yang dibutuhkan, seberapa besar dan pentingnya kebutuhan tersebut bagi calon nasabah. Kebutuhan dapat dipenuhi dari aspek fungsional produk yang ditawarkan, misalnya saja kebutuhan seorang nasabah menabung di Bank adalah untuk berinvestasi, keingginannya tentu lebih dari berinvestasi, tetapi keamanan, prestise, mendapatkan kemudahan fasilitas, atau yang lainnya.

Semakin maju kesadaran pelanggan dan semakin banyak pilihan produk (barang/jasa) yang ditawarkan oleh produsen, pelanggan menjadi semakin sulit dilayani, menjadi lebih sadar harga, menjadi semakin penuntut tentang kriteria produk yang dikendaki. Kenyataan tersebut menantang perusahaan untuk tidak saja memperoleh pelanggan yang puas, tetapi juga memberikan kepuasan pelanggan yang lebih puas hingga sampai pada pelangan yang loyal.

Penampilan seorang marketing juga tidak kalah penting bagi seorang marketing untuk menarik minat calon nasabah misalnya, berpakaian rapi, berpenampilan menarik, murah senyum, sopan dan santun.

a. Penampilan,dari fasilitas fisik, peralatan, orang, maupun alat komunikasi yang dijanjikan. Zaman yang semakin modern, maka diperlukan penampilan yang modern tentunya diperlukan untuk memuaskan seorang pelangan. Oleh karena itu, penampilan seorang marketing dan desain lantas memegang peranan semakin penting, baik di dalam produk yang akan dipromosikan itu sendiri maupun di dalam sarana penunjangnya, 
b. Menunjukkan kemampuan produsen untuk melakukan service yang dijanjiksm secara cermat dan tepat,

c. Mental melayani konsumen, harus timbul dari hati sanubari dan "mendarah-daging", bukan Cuma sekedar karena keharusan,

d. Pengetahuan dan keterampilan untuk melayani yang memadai hal tersebut tentunya tidak dapat terlaksana dengan baik. Begitu pula dengan keramahan, dan

e. Berempati, terjadinya komunikasi dua arah anatara produsen dan konsumen, setelah itu produsen harus mencoba mengerti konsumen, ber empati tidak hanya mengiyakan tuntutan konsumen, paling tidak produsen harus menunjukan bahwa dia mau mengerti masalah yang ada dikonsumen dari sudut pandang mereka.

Berdasarkan pendapat diatas ketika dilapangan terlihat bahwa marketing BRI syariah telah memiliki kepandaian tersebut, hal ini terlihat dari banyaknya calon nasabah yang tertarik untuk membuka tabungan Faedah (menurut data terdapat 28.613 account rekening).

Dari segi penampilan seorang marketing BRI Syariah terlihat bahwa:

a. Berpenampilan menarik, seperti berpakaian rapi dan harum, bersih,

b. Menunjukkan kemampuan dalam hal mempromosikan suatu produk dengan cermat dan tepat hinnga ketika seorang marketing menjelaskan, calon nasabah dapat mencerna dan menggerti apa yang dipaparkan baik itu penjelasan ataupun janji oleh marketing tersebut,

c. Mental melayani calon nasabah, ketika marketing berhadapan langsung dengan calon nasabah, sopan santun sangat diperlukan

d. Pengetahuan dan keterampilan untuk melayani seorang nasabah yang memadai sehinnga tertarik menggunakan produk tabungan Faedah di BRI syariah KC Banjarmasin,

e. Berempati memahami apa yang dibutuhkan oleh calon nasabah, baik itu keluhan mereka harus murah senyum.

Sehingga ketika calon nasabah berhadapan dengan marketing tersebut mereka merasa nyaman untuk menerima promosi-promosi yang ditawarkan. Ini dibuktikan ketika banyaknya pertanyaan dari calon nasabah terhadap produk yang ditawarkan seorang marketing. Sarana promosi dalam rangka memberikan promosi penjual, dan publisitas, pihak BRI syariah menerapkan Strategi ofensif (untuk memperoleh nasabah baru) dan defensif (untuk mempertahankan nasabah yang sekarang) dengan melakukan pemberian insentif kepada setiap nasabah yang memiliki simpanan saldo tertentu, semakin besar simpanan saldo maka akan semakin besar pula insentif yang didapatkan. Hal ini dapat terlihat dari data yang didapatkan peneliti saat melakukan wawancara dengan pihak BRI Syariah. Selain itu pemberian cendera mata, hadiah, serta kenang-kenangan lainnya kepada nasabah yang loyal juga menjadi promosi yang mampu membuat nasabah merasa puas.

Menurut Fandy Tjiptono, pada beberapa manfaat yang bisa didapatkan pihak Bank yang nasabahnya merasa puas terhadap produknya, diantara manfaatnya adalah (Tjiptono, 1997):

a. Hubungan perusahaan dengan anggota semakin harmonis,

b. Memberikan dasar yang baik bagi pembelian ulang,

c. Membentuk rekomendasi dari mulut kemulut untuk membeli produknya dan menguntungkan perusahaan,

d. Reputasi perusahan menjadi baik bagi nasabah,

e. Laba perusahan dapat meningkat, dan

f. Penjualan pribadi kepada nasabah diberikan secara optimal oleh pihak perusahaan. 


\subsection{Analisis SWOT Strategi Promosi Tabungan Faedah di BRI Syariah KC Banjarmasin}

Menurut Philip Kotler pengertian analisis SWOT adalah evaluasi terhadap semua kekuatan, kelemahan, peluang, dan ancaman, yang terdapat pada individu atau organisasi (Kotler, 2001). Dengan analisis SWOT memungkinkan perusahaan untuk mengidentifikasi faktor-faktor yang mempengaruhi baik positif maupun negatif dari dalam dan dari luar perusahaan. Peran kunci dari SWOT adalah untuk membantu mengembangkan kesadaran penuh dari semua faktor yang dapat mempengaruhi perencanaan strategi dan pengambilan keputusan, tujuan yang dapat diterapkan pada hampir semua aspek industri.

Analisis ini bermanfaat untuk mengetahui suatu permasalahan dari empat sisi yang berbeda, yaitu kekuatan, kelemahan, peluang, dan ancaman, yang dimiliki oleh sebuah perusahaan. Hasil dari analisis ini dapat memberikan rekomendasi untuk meningkatkan kekuatan dan mempertahankan peluang, serta pada saat yang bersamaan mengurangi kelemahan dan menghindari potensi ancaman (Fahmi, 2010).

Analisis SWOT merupakan suatu faktor internal dan faktor eksternal BRI Syariah, cara mengetahui gambaran perkembangan strategi promosi tabungan Faedah di BRI syariah KC Banjarmasin, kegiatan analisi ini dilakukan agar stretegi promosi tabungan Faedah agar dipertangung jawabkan berdasarkan fakta-dan dasar yang kuat, diantaranya sebagai berikut:

a. Kekuatan

Berdasarkan hasil wawancara dengan Sofyan (2019) dinyatakan bahwa kekuatan dari tabungan Faedah adalah BRI Syariah mempunyai struktur permodalan yang kuat.

Struktur modal merupakan maslah penting bagi perusahaan karena baik buruknya struktur modal akan mempunyai efek langsung terhadap posisi finansial perusahaan, struktur modal yang akan mengoptimalkan keseimbangan antara risiko dan pengembalian sehingga memaksimumkan harga saham. Dari segi perkembangan teknologi BRI Syariah telah mempunyai sistem yang tidak kalah bersaing dengan bank lain dalam memberikan pelayanan yang maksimal kepada nasabah baik secara langsung maupun tidak, secara Onlie dan Offline. Hal ini terbukti dari adanya pelayanan E-Banking, SMS Banking, Mobile Banking, Cash Management System, e-From, dan laku pandai.

b. Kelemahan

Setiap ada kekuatan tentunya ada kelemahan, begitu pula dengan BRI Syariah KC Banjarmasin, terhitung masih berusia muda dibandingan dengan bank konvensional, maka pengetahuan masyarakat terhadap Bank Syariah tentunya lebih sedikit dibandingkan dengan Bank Konvensional. Masih terbatasnya jumlah Bank Syariah yang ada ditengah masyarakat, Perkantoran dan jaringan ATM Bank Syariah yang hanya ada ditengah Kota menyebabkan masyarakat masih kurang banyak mengenal Bank Syariah jika dibandingkan dengan Bank Konvensional yang telah membuka Unit di tingkat Kecamatan.Selain itu, kurangnya sosialisasi tentang Bank Syariah dan fakta bahwa masyarakat masih banyak yang membandingkan antara jumlah atau rasio bagi hasil yang ditawarkan Bank Syariah dengan jumlah bunga yang ada di Bank Konvensional juga menjadi alasan masih sedikitnya nasabah Bank Syariah dibandingkan dengan Konvensional. 
c. Peluang

Mayoritas penduduk Kalimantan Selatan yang kebanyakan memeluk agama Islam terkhususnya di Kota Banjarmasin, dapat membuat BRI syariah berkembang pesat dan cepat hingga apalagi seluruh masyarakat muslim lebih memilih untuk memanfaatkan bank yang berbasis syariah dari pada bank konvensional. Selain itu juga fatwa mengenai bunga bank juga ikut menjadikan bank syariah menjadi lebih sehat dan terpercaya untuk melakukan transaksitransaksi bermuammalah.

d. Tantangan

Selain adanya peluang dalam BRI Syariah, maka ada pula yang dinamakannya sebuah tantangan yang harus dipecahkan, sampai saat ini, BRI Syariah dapat dikatan belum terlalu mapan, masih ada beberapa hal yang perlu dibenahi, terutama dalam hal manajemen, tugas dan wewenang, peraturan, dan struktur keorganisasian. Hubungan antara bank konvensional dengan perbankan syariah juga perlu diperjelas agar ke depannya lebih sinergis. Selajutnya dengan masih ada masyarakat yag memandang bahwa perbankan syariah dengan senyum sinis, terjadi mispersepsi, seolah bank syariah itu ekslusif (hanya untuk orang Islam saja) namun untuk nonmuslim pun boleh membuka tabungan atau melakukan pembiayaan di BRI Syariah. Sistem bagi hasil yang kurang menguntungkan dan susah prosesnya, oleh sebab itu tentunya menjadi tantangan besar bagi pihak BRI Syariah untuk bisa berusaha mengubah pemikiran masyarakat yang memilki mindset seperti itu.

\section{Kesimpulan}

Strategi promosi tabungan Faedah yang dilakukan BRI Syariah KC Bajarmasin yang dilakukan berupa: promosi ketika serbu pasar, kesekolahan SD, SMP, SMA, perusahaan, keperkuliahan, bekerjasama dengan beberapa perusahaan dan ke calon nasabah yang ingin melakukan pembiayaan. Berdasarkan analisis SWOT, BRI Syariah KC Banjarmasin masih memiliki banyak tantangan dan kelemahan yang harus dibenahi agar promosi yang dilakukan berhasil dan membantu menambah dana pihak ketiga pada BRI Syariah KC. Banjarmasin tersebut. BRI Syariah KC Banjarmasin dapat menggunakan kekuatan untuk mengatasi kelemahan dan tantangan, dan juga dapat mengoptimalkan peluang agar tantangan dan kelemahan dapat dihilangkan.

\section{Referensi}

Rosmadi, M. L. (2021). Penerapan Strategi Bisnis di Masa Pandemi Covid-19. Jurnal IKRA-ITH Ekonomika Vol 4 No 1, 122-127.

Ariyani. (2017). Pengelolaan dan Mekanisme Tabungan Faedah Di BRISyariah KC Banjarmasin. Palangkaraya: IAIN Palangkaraya.

Fahmi, I. (2010). Manajemen Risiko. Yogyakarta: Alfabeta.

Handayani, S. (2018, September 5). Funding Relation Officier BRI Syariah KC. Banjarmasin. Hasanah, U. (2017). Strategi Promosi Pembiayaan Sebagai Uapaya Peningkatan Jumlab Sasaran Pada PT. BRI Syariah KCP Pasar Baru di Kota Banjarmasin. Palangkaraya: IAIN Palangkaraya.

Hasbi, M. (2019, Februari 28). Manajer Operasional BRI Syariah KC. Banjarmasin.

Kaluku, F., Mandey, S. L., \& Soepeno, D. (2018). Analisis Bauran Promosi Terhadap Keputusan Nasabah Menggunakan Produk Unggulan Pada Bank Syariah Mandiri Cabang Manado. Jurnal EMBA, Vol. 6, No. 2, 888-897. 
Analisis Strategi Promosi Tabungan Faedah PT. BRI Syariah KC. Banjarmasin...

Kasmir. (2012). Dasar-dasar Perbankan . Jakarta: Rajawali Press.

Kotler, P. (2001). Manajemen Pemasaran di Indonesia. Jakarta: Salemba Empat.

Ma'arif, N. N. (2008). The Power of Marketing : Practioner Perspective in Asia. Jakarta: Salemba Empat.

Maisyarah. (2017). Pengaruh Strategi Promosi Produk Tabungan Simpel IB Hasanah PT. BNI KCS Banjarmasin Terhadap keputusan Menabungn Pelajar SMAN 7 Banjarmasin. Palangkaraya: IAIN Palangkaraya.

Moekijat. (2000). Manajemen Pemasaran. Bandung : Mandar Maju.

Nana, H. A. (2013). Manajemen Bisnis Syariah dan Kewirausahaan. Bandung: CV. Pustaka Setia.

Sofyan, R. A. (2019, Februari 13). Account Officier BRI Syariah KC. Banjarmasin.

Suryaputra, F. A., Bandi, \& Setiawan, D. (2017). Perkembangan Penelitian Kinerja Perbankan di Indonesia. Akuntansi dan Bisnis Vol. 17 No. 2, 88-99.

Tjiptono, F. (1997). Strategi Pemasaran. Yogyakarta: Penerbit Andi.

Waroh, M. R. (2020). Strategi Promosi Produk Tabungan Haji di Bank Mandiri Syariah Kantor Cabang Pembantu Blitar. Ponorogo: IAIN Ponorogo. 